\title{
IRISH FILM AND TELEVISION - 2011
}

The Year in Review

Roddy Flynn, Tony Tracy (eds.)

Copyright (c) 2012 by the authors. This text may be archived and redistributed both in electronic form and in hard copy, provided that the authors and journal are properly cited and no fee is charged for access.

Irish Film 2011. Introduction

Roddy Flynn

"Not in front of the American": place, parochialism and linguistic play

in John Michael McDonagh's The Guard

Laura Canning

From Rural Electrification to Rural Pornification:

Sensation's Poetics of Dehumanisation

Debbie Ging and Laura Canning

Ballymun Lullaby

Dennis Murphy

Ballymun Lullaby: Community Film Goes Mainstream

Eileen Leahy

The Other Side of Sleep

Tony Tracy

A Changing Subject-Position for Travellers in Knuckle

Eileen Leahy

Love/Hate - Series Two

Paul McGuirk

Gabriel Byrne - Liminal Man

Roddy Flynn

\section{Irish Film and Television Review 2011. Introduction}

Roddy Flynn

On March 10 2012, The Irish Times reported that Ardmore Studios, the facility which since 1958 has in one way or another symbolized the attempt to establish a film industry in Ireland, faced closure owing to a lack of activity at the studio. Ardmore has faced "The End" before: in 1963, 1967, 1973 and 1982 it variously entered receivership, went bankrupt or was simply closed. On every occasion, the studio reemerged, often re-capitalised by the state. However that the current threatened closure may genuinely be the final curtain reflects shifts in the structure of the Irish audiovisual sector which have become particularly manifest over the past twelve months. 
The 1990s and 2000s were easily the most successful decades in Ardmore's history, as the facility benefitted from the general increase in film and television production levels that followed the re-establishment of the Film Board, the creation of the Independent Production Unit in RTE and the expansion of tax breaks for audiovisual investment.

It might therefore be reasonable to assume that Ardmore's current difficulties point to a decline in production activity in Ireland. In fact, the opposite is the case. When IBEC published its annual audit of production in Autumn 2011, it noted that the value of the Irish audiovisual sector in terms of output had leapt from $€ 243.3 \mathrm{~m}$ in 2009 to $€ 387.9 \mathrm{~m}$ in 2010. However, drilling down into that overall figure reveals dramatic changes in the sector over the past decade. In 2003, 70\% of audiovisual production in Ireland was accounted for by feature film production. By 2007, however, feature production's share of output had fallen to less than $10 \%$. In its stead, independent television production has come to the fore, accounting for $62 \%$ of all production activity in 2010.

This shift to television owes much to rise of US cable networks since the late 1990s, which brought cinema-style production values and significantly enhanced budgets to television drama production. And just as in the 1990s US film producers looked overseas for countries which would allow them to eke value out of every last cent of their production budgets, the last five years have seen a number of large-scale US television productions touch down in Ireland, leaving tens of millions of dollars in the hands of Irish cast, crew and facilities companies. The Tudors, Camelot and Game of Thrones (the last shot in Northern Ireland but entirely postproduced by Screen Scene in Dublin) have all contributed to production activity here since 2006, availing of both the Section 481 tax-break and dipping into the Irish Film Board's International Production Fund. 2011 and 2012 have seen or will see further large-scale productions shoot here such as the Morgan O'Sullivan production, Vikings for MGM Television, and the Italian-funded Titanic: Blood and Steel mini-series for RAI.

The four seasons of the Morgan O'Sullivanproduced The Tudors were particularly crucial to
Ardmore's viability between 2006 and 2009. That it was almost immediately replaced by Camelot (another Morgan O'Sullivan production, this time for the Starz network) kept the ball rolling for the studios. However, the increased level of television production created its own difficulties. The presence of Camelot in 2010/11 meant that another production, Showtime's The Borgias (created by Neil Jordan and co-produced by Octogon's James Flynn) couldn't even contemplate shooting in Ireland because of the lack of studio space: that production was largely shot in Hungary instead. However, this apparently unfulfilled potential demand, encouraged entrepreneur Joe O'Connell to proceed with the construction of a competing set of studios 20 minutes down the N11 from Bray in Ballyhenry near Ashford, Co. Wicklow.

The design of Ballyhenry's three sound stages addressed a key difficulty faced by Ardmore: scale. The significance of this consideration has been emphasized by the particular nature of the television dramas which have come to Ireland in recent years: they have all been set in period or fantasy contexts. This demands the extensive use of Green Screen technology to create the settings for the productions. This in turn requires largerscale (in excess of 12,000 square feet) studio spaces. Ardmore, a facility originally constructed in a very different film-making era has one such sound stage: Ballyhenry has three.

Thus when the Starz network declined to renew Camelot, Ardmore (and Ireland) lost a production which had spent $€ 32 \mathrm{~m}$ in the previous year. But that loss was compounded by the news that Vikings seems likely to be shot in Ballyhenry with the result that Ardmore has had no major projects onsite books since early summer 2011.

The apparent ascent of Ballyhenry and the possible demise of Ardmore suggest a scaling up in Irish production and reflect the current emphasis of state audiovisual policy. In the aftermath of the February 2011 election a new Fine Gael/Labour coalition came into office. The new Minister for Arts, Heritage and the Gaeltacht is Jimmy Deenihan, a Fine Gael TD (and former Kerry footballer) who, following the practice of most of his predecessors, lost no time commissioning a report on the future of the Irish audiovisual industry which was published in July 
2011. Entitled "Creative Capital" the report recommended a number of strategies aimed at increasing the value of the Irish audiovisual sector to over €1bn and related employment to 10,000 by 2016.

Amongst other recommendations, the report suggested radically overhauling the Irish Film Board to allow it to act as "a specialist development agency for the entire audiovisual industry alongside its current remit of developing the industry for the making of Irish film and television"1 and suggested that responsibility for administering the Sound and Vision scheme (which supports independent television production with funds from television licence fee income) should be transferred from the Broadcasting Authority of Ireland to the Film Board in the interests of "greater national policy coherence". Given the stress elsewhere in the report on the need to develop strong indigenous companies, it is hard to avoid the conclusion that this would mean that the Board might focus its support on companies active in both film and television production in the interests of allowing the latter to scale up.

"Scaling up" may also inform the report's stress on the need to establish strategic partnerships between the putative new Irish Film Board and each of Ireland's indigenous broadcasters setting out "common ground for feature, TV drama, animation, documentary production and industry training” (ibid, p.16). At a time of national financial retrenchment, there is a stress throughout Government on ensuring that what money is spent is concentrated on productive activities. The report appears to suggest applying the same logic to the audiovisual sector, encouraging the Film Board and the Broadcasters to pool their expenditures to produce films and programmes which can succeed on a market basis. This stress on coordinating film and television production seems logical if one accepts that there's a link between strong domestic broadcasting markets and the level and quality of film, TV drama and animation output.

1. Audiovisual Strategic Review Steering Group (2011), Creative Capital, Dublin: Government Publications, p. 19.
However, the report's insistence that such transformations should be "cost neutral" were problematic given the ongoing financial woes of the economy as a whole. In December 2011, it was announced that the total funding for the Department of Arts, Heritage and the Gaeltacht would fall to $€ 266 \mathrm{~m}$ for 2012 whilst the Irish Film Board's capital budget (i.e. the money actually spent on development and production of films) would fall from $€ 16 \mathrm{~m}$ to $€ 13.1 \mathrm{~m}$. On the other hand, the Board's administrative budget was increased by $4 \%$, perhaps in anticipation of a re-tooling the Film Board along the lines proposed in the "Creative Capital" report.

Furthermore, various announcements from RTE and TV3 during 2011 did little to raise expectations that the broadcasters could make significant contributions to developing the audiovisual sector as a whole. The continuing contraction of the television advertising market continued to place all broadcasters under pressure. TV3 introduced a voluntary redundancy scheme in August, albeit on a small scale. RTE experienced even greater financial pressures: not merely did it continue to lose ad revenue but it watched as an increasing proportion of the licence fee bypassed the station and went to the Sound and Vision scheme. Facing a deficit of $€ 17 \mathrm{~m}$ for 2011, RTE is now in a period of retrenchment. Director-General Noel Curran identified "investigative journalism, arts and culture, children and young people, innovation, 24 hour news and national events" as areas the station would seek to protect and enhance but it was notable that more costly areas like drama production were not included on that list.

By contrast, TV3 announced during the year that it was building two new studios at their Ballymount facility to produce more homegrown material - 50 hours a week - than ever before. However, that additional output looks likely to be low-cost, invariably studio-based and almost wholly based on UK formats. Come Dine with $\mathrm{Me}$, a reboot of Mastermind, Family Fortunes and Tallafornia (based on Geordie Shore itself based on Jersey Shore) do not seem likely to spearhead international sales.

2. From text of speech delivered by Noel Curran at The Helix, Dublin City University 17 $7^{\text {th }}$ October 2011. 
That said, RTE are still the only producers of indigenous television drama. In addition to soap Fair City, 2011 and 2012 have seen the return of the gangster drama Love/Hate (reviewed here) and the restaurant-set Raw. RTE comedy, once regarded as a contradiction in terms also seemed to find a second wind. Hardy Bucks, a product of RTE's “Storyland" slot from 2009, returned for a second series, with a welcome focus on a Midlands Ireland often absent from the small screen (see review of The Other Side of Sleep). David McSavage's The Savage Eye found respectable audiences on RTE2 Television as it skewered the pretensions of Irish society, and perfectly captured public fury at the performance of the Irish political class over the past decades. Bizarrely it was eclipsed by the success of the BBC/RTE co-production Mrs Brown's Boys, centred on comedian Brendan O'Carroll's performance as the eponymous Mrs Brown, a working class Dublin housewife. O'Carroll's "Mrs Brown" has been around for decades, on stage and in book form (and indeed on the big screen as performed by Angelica Huston in the 1996 film Agnes Brown.) The character's small screen incarnation met with a negative reaction from critics in Ireland and the UK, who regarded its broad-humour, lead character in drag and studio setting as a throwback to sitcoms of the 1970s and 1980s. Audiences, however, have flocked to the show - the show's 2011 season averaged over 700,000 viewers on RTE - and in a populist nod, BAFTA included it amongst the nominees for Best Television Comedy in April 2011 (it didn't win).

Strikingly absent from "serious" television drama was work reflecting and exploring the impact of the economic crisis (now in its fourth year). It's obliquely referenced in Raw but the focus there remains on the internal lives of the characters rather than the social context they live in.

The same is not universally true on the big screen. Darragh Byrne's Parked drew a remarkably-sympathetic performance from Colm Meaney, as Fred, a middle-aged man, reduced to living in his car by the recession. The film was well-received critically and its success in festivals on both sides of the Atlantic raise the prospect that it may receive wider distribution than the short run it received domestically.
Indeed that it received a theatrical release even in Ireland made it unusual. Of the 44 films listed by the Irish Film Board as having been produced with its involvement since 2010, 14 have received any kind of release in Ireland. Even allowing for the fact that some of these are still in post-production the difficulty that Irish feature films continue to encounter in reaching audiences is disappointing. In summer 2011, Setanta Ireland ran a season of Irish films every weekday night, films which as IFB Chief Exec James Hickey discreetly put it, audiences "may not otherwise have a chance to see."3

Among the 14 that were released were The Runway, Snap, Rewind, Wake Wood, Sensation (reviewed below), Between the Canals, The Other Side of Sleep (reviewed below) and the poorly received Stephen Soderbergh film Haywire (which was at least notable for featuring what is arguably the first blockbuster-style chase sequence through the streets of Dublin). A number of documentaries supported by the Film Board also found audiences on the small screen: Pyjama Girls, Ballymun Lullaby and Knuckle (the latter two reviewed below). By far the biggest Irish film in 2011 was John MacDonagh's The Guard which in the process of taking $€ 4.13 \mathrm{~m}$ at Irish box office became the most successful independent Irish film ever released here (surpassing The Wind That Shakes the Barley). That this occurred against the backdrop of declining cinema attendances (which have fallen steadily since their 2007 of $18.4 \mathrm{~m}$ admissions to $16.5 \mathrm{~m}$ in 2010 ) is all the more remarkable.

Producer of The Guard, Ed Guiney's reflections echoed the conclusions of "Creative Culture" on scaling up. Interviewed by iftn.ie, he argued that rather than simply trying to attract UK and US production

We should be making those films ourselves instead of just trying to attract them in. We need to be making more films on the same scale as The Guard. We have had a lot of lower budget productions, around a million euro or less, and

3. "Irish Films For All On Setanta Ireland" from www.iftn.ie/news. Accessed at http://iftn.ie/news/ BroadcastNews/?act1=record\&only=1\&aid=73\&rid= 4284031\&tpl=archnews\&force=1 7 March 2012. 
that is totally valid. But what we haven't had a lot of recently are medium budget film, around a four or five million budget, like The Guard or Shadow Dancers. ${ }^{4}$

Guiney and his partner Andrew Lowe have already made significant progress in terms of scale. Already working both as a producer and within Ireland - a distributor, their company Element Pictures moved into the online world with the launch of Volta Online in Spring 2012, making available a host of little-seen Irish films (not necessarily produced by Element or any of Guiney's earlier ventures) to, hopefully, new audiences. In a similar vein, although the Light House cinema in Dublin's Smithfield closed in April 2011 after three years of operation when the owners were unable to meet increased rental charges, in February 2012, the Light House reopened it doors (just in time for the Jameson Dublin International Film Festival) again under the management of Element.The year ended on a similarly upbeat note with the inclusion of four Irish-related films among the Oscar Nominations. Relative neophyte producer Eimear O'Kane saw her short film Pentecost nominated in the best short film category alongside the eventual category winner, the Terry George-directed The Shore. There were also nominations for Kenneth Branagh as best supporting actor and make-up artist Lynn Johnston for her work on Albert Nobbs which was shot in Dublin during 2011. Perhaps more surprising was the absence of a nomination for the apparently omnipresent Michael Fassbender, who turned in a harrowing performance in Steve McQueen's Shame. Indeed, 2011 was a year in which a rake of Irish actors, suddenly appeared (in some cases reappeared) on

4. Mandy Hegarty (2011) "Irish Producer Ed Guiney on The Guard" posted July 42011 on www.iftn.ie.

Accessed at http://iftn.ie/news/

featureinterviews/?act1=record \&only=1\&aid=73\&rid= 4284049\&tpl=archnews\&force=1 1 March 2012. the international radar on both the big and small screens: Saoirse Ronan, Robert Sheehan, Amy Huberman, Sarah Bolger, Andrew Scott, Antonia Campbell Hughes, Kerry Condon and Eva Birthwhistle all came to prominence in a year in which sadly, two leading lights were extinguished in the guise of Alan Devlin and David Kelly.

In sum then, in spite of adverse economic conditions in 2011 the Irish Film and TV sector was vibrant, active and in some quarters deeply ambitious. However it was in a state of unprecedented transition. With the imminent closure of Ardmore, that venerable symbol of Ireland's long held, often postponed ambition to make images of itself for the big screen, we can identify a real and symbolic shift away from an industry predicated on the model of indigenous feature film production towards an entertainment industry caught in the flow in transnational capital. It is notable that the 'rising stars' mentioned above all came to prominence or revived their careers in TV drama, in contrast to the traditional progress of Irish actors from (national) stage to (international) big screen. At the same time the cultural capital of feature films has progressively diminished, the success of the occasional breakout film like The Guard (benefitting from two stars and a considerable marketing budget) notwithstanding. While there is more work in the audiovisual sector than at any time before, challenges of distribution mean that a significant number of Irish films now go unseen outside of the festival circuit. From the current vantage point then, and in light of policy shifts outlined earlier, it seems that film will become an increasingly niche activity of the sector as a whole.

Roddy Flynn is a lecturer on film and television at the School of Communications, Dublin City University. 


\section{"Not in front of the American": place, parochialism and linguistic play in John Michael McDonagh's The Guard (2011).}

\section{Laura Canning}

That John Michael McDonagh's The Guard became, in 2011, the most successful independent Irish film in Irish box office history, must be a source of cheer to the beleaguered Irish Film Board. However the work itself, a Galway-set hybrid of spaghetti western and the New British and Irish gangster dramas of the 1990s and early 2000s, has been greeted in uncritical terms, with exploration of its themes and frames abandoned in favour of a naïve celebratory discourse which has privileged 'market value' and industry awards over textual or stylistic innovation. While The Guard attempts to cast a fresh eye over ossified genre conventions, this film too features an unlikely protagonist - the titular Guard being Sergeant Gerry Boyle (Brendan Gleeson), a law enforcement officer in rural West Galway - who finds himself entangled with a ruthlessly amoral criminal gang amid a series of blackly comic and occasionally shockingly violent incidents, concluding in a Pyrrhic rather than conclusive climactic victory over them. Owing more to the theatricality of Synge than it does to any cinematic antecedents, despite its subTarantinian litany of cultural references, it is primarily the intensity of its desire for an extreme 'localisation' of the genre that marks it out.

Parochialism is a key characteristic of The Guard. Ireland here appears as some kindred of the American West, complete with bar brawls and blunderbusses, but defined also by the sort of whimsical eccentricity that has dominated representations of Ireland since before The Quiet Man. Characters - although safely 'rooted' in the contemporary by clunky references to lattes and cappuccinos - are defined explicitly and obsessively in relation to what seems a distinctly pre-modern and xenophobic emphasis on locale. All are defined through their presumed geographic origins or genealogy, whether a suspect incensed at being called "a fucking Italian”, a murdered Garda’s widow mistaken for a Romanian (on finding she is Croatian, the solemn endorsement of "Good footballers, the Croatians" is bestowed), or via repeated references by the drug traffickers that Boyle and his beleaguered American counterpart FBI Agent Wendell Everett (Don Cheadle) are hunting, to "the fucking English".

These last are double-coded to leave space for a critical reading of the Irish as unpleasantly obsessed with their own oppression - we are told, "That's the trouble with the Irish...they never forget" - but the point lacks interrogative sharpness, its ultimate expression coming when an IRA operative states, harking back to the era of Kim Philby and associates, that gay agents were "the only way we could successfully infiltrate the MI5", simultaneously pejoratively linking associations of Englishness and homosexuality, and seeming to claim a kind of quasi-progressive status for the IRA and by extension the Irish. This winking feint-and-parry style is employed throughout, with McDonagh approaching each tendentious point close enough to deliver an obvious gag without exploring further. The result is acutely self-conscious, the film weighed down by non-sequiturs as it progresses towards its Mexican stand-off conclusion.

The film reserves a special place for "the Dubs”, producing a mixture of straightforward comic insults ("fuck off back to Dublin"; the insinuation that an STD is the only logical outcome of sex with Dublin women), and a more complex challenging of presumed metropolitan 
attitudes to Boyle's "lowly country nobody", a phrase misheard by ill-fated new partner McBride (Rory Keenan) as "lonely country nobody". Hints of a more subtle take on the urban-rural divide emerge, but the overall picture is of a - successful, if perhaps cynical - attempt to co-opt rural audiences into accomplices, positioning them as members of a countermovement to the dominance of images of the capital in contemporary Irish cinema. However, this appeal to localism frequently swings into an intensely venial parochialism that, paradoxically, has a simultaneous wide common appeal; the film's international success indicates that the categorisations on offer could as easily be transported to Swindon or Cleveland and be as relevant, and as negative, as they are here.

Local knowledge is repeatedly emphasized as superior to any other, with Boyle's access trumping Everett's by-the-book investigation, and insularity presented as a quality intrinsic to the Irish, and as a legitimised source of pride, as we see Everett canvassing uninterested GAA fans and being ejected for not being from a 'glamorous' enough division of the FBI. One set-piece revolves around a family of Gaelgóirí who refuse to respond to him in English, protesting that "this is Ireland. Go over to England if you want to speak English". Here, the complex realities of Irish-language debates are ignored in favour of a momentary symbolic resistance to the supposed encroachment of English-language culture that only serves to emphasise McDonagh's distance from and lack of engagement with the 'real' Ireland.

It is America that seems to loom just offshore in this imagined Ireland; not so much the 'land of opportunity' of a few generations ago, as the bedrock of a seam of running pop-culture references and jokes. These encompass the mocking of the phrases 'John Doe' and "putting out an APB", multiple police procedural show references, a slang comment greeted with "He thinks he's in fucking Detroit”, and Boyle's bonding with Everett over the mention of Tupelo, Mississippi - birthplace of Elvis, but also Everett's wife's home town, calling to mind the traditional Irish practice of 'tracing' parish origins. They also serve to highlight the debt that The Guard owes to Tarantino and his imitators, as evinced by a scene in which gang leader Francis Sheehy-Skeffington (presumably a tricksy reference to the Irish suffragist and pacifist of the same name) asks the question "what did they throw off the Tallahatchie Bridge?" Here, American pop culture is more at issue than anything distinctively Irish, and Boyle's function seems designed to appeal to presumed insecurities: a surrogate who 'gets one over' not on our old colonial masters, but our new ones, the Americans, this mastery-throughbonding complicated through Everett's positioning as an African-American.

Distinctive, too, is the way in which The Guard uses transgression, and specifically transgressive language play, as a source of humour. Provocation is emphasised, with references to bestiality, a paraplegic described as a 'spastic', and Boyle mockingly asking McBride if he has "interfered" with a corpse before. The references are complicated by their framing not just as specific comedic devices, but as attacks on assumptions Boyle appears to believe others (Dubliners, Americans) make about the rural Irish. However, these assumptions are not borne out by characters' behaviour, which makes his pre-emptive attacks on what might be termed "PC attitudes" unwarrantedly bitter and gratuitous; in emphasising supposed Dublin-rural and IrishAmerican value contrasts, and privileging an atavistic interpretation of Irish attitudes - "Ah would you fuck off to America with your 'appropriate'" - the film valorises humourless hectoring over genuine verbal dexterity.

It is the disingenuousness of this stance that strikes a disquieting tone. Boyle is positioned as a man whose motivation is to "tell it like he sees it', whether admiring the "enterprise" of Colombian drug exporters, professing that babies look the same unless they are exceptionally ugly, or cheerfully recounting his drug use to Everett, and it is his use of language as a weapon - in a distinctly theatrical, not cinematic, fashion - that rings loudest. Through Boyle, McDonagh may attempt to recuperate the 'village idiot' of The Quiet Man or Ryan's Daughter, but the ferocity of his verbal attacks are not diminished by his "Would you lighten up, for fuck's sake", the bully's disclaimer of "I'm only having a bit of fun, like.” Boyle may 'tell it like he sees it' but this is at the expense of other, more vulnerable 
characters.

The prostitutes he gleefully patronises, dressed in parody uniform, are simpering 'happy hooker' ciphers, and Boyle is ignorant of his responsibility for the beating one of them receives. When she states "there are no nice fellas" he replies “I wouldn't be too sure about that now", denying his complicity in her sexual servitude, reducing their transaction to a simple free-market exchange. When Boyle publicly declares "I thought only black lads were drug dealers. And Mexicans” and is censured by the corrupt, dimwitted Inspector Stanton, he retorts “Apologise for what?...I'm Irish, shur, racism is part of my culture" he is on the brink of positing a challenging thesis about contemporary Ireland. McDonagh discards the opportunity, however, the situation merely a set-up to highlight Boyle's anti-establishment credentials, rather than an attempt to explore the film's - or Ireland's leanings towards xenophobia.

While The Guard sells itself as a no-holdsbarred comedy, it notably has a sudden attack of conscience when Boyle upbraids IRA man Hennessey (Pat Shortt) on the ethics of combat, saying "It's not as if you lads were ever that keen on getting in close for a scrap now, was it? Blowing up Australians by mistake from a distance was more your modus operandi." Given McDonagh's cheerful skewering of 'spastics', prostitutes and 'Romanians', and references to the FBI being "more used to shooting at unarmed women and children" this reflects a degree of post-ceasefire delicacy that could be regarded as creatively craven, or born of the necessity to cultivate Britain as a marketplace. Hennessey may be a cheerfully bucolic 'cute hoor', but the film represents republicanism and the IRA through a ferociously conventional framework of moral unacceptability.

It is the verbal ritual of 'slagging' which dominates The Guard, as Boyle's bonding with Everett reveals. From questions about growing up in "the projects" to noting "I thought black people couldn't ski”, language functions primarily as display, or masculine challenge given and accepted. Boyle's racist play with words forms a paradoxical bonding activity; male friendship solidified by the kind of verbal abuse that, we are to infer, only a 'real' Irishman can deliver. Mastery of language, it implies, is mastery of all, whether used as much to hide as it is to reveal, as in the case of the tight-lipped locals Everett compares to the residents of Compton as "not too keen on talking to the law", or to display status and exert control, as with the verbose drug traffickers who exchange favourite philosophers' aphorisms, decry Americanisms, and argue over correct clinical definitions of the words 'sociopath' and 'psychopath'.

The film's broad call to cultural knowledge and status - the references to Chet Baker and Russian literature as well as philosophy - is worn heavily and while McDonagh may be championing a culturally sophisticated image of Ireland, it feels like a more cynical exploitation of literary and intellectual heritage, designed to substitute scattershot references for anything deeper. However, in many cases this is masked by Gleeson's fine work in humanising an inconsistently-written and often gratingly charmless character.

Unfortunately McDonagh lacks the imaginative edge and visual daring that would elevate The Guard beyond its overly-wordy sophistry. Despite some entertaining comedic moments, an often nuanced approach to the rhetorical discourse of the drugs trade and lawenforcement, and a sensitively observed motherson relationship, the gangster tropes employed here are too tired to be easily resuscitated, and McDonagh opts for irreverence over real intensity. In the end, aside from the interesting implication that Ireland is so corrupt it must be escaped from, no trace left behind, it is Boyle's combination of winking whimsy and swaggering contrarianism that prevails, a vision of Irish manhood that panders to parochialism while claiming the virtues of subversive individualism.

\section{The Guard (2011)}

Dir: John McDonagh

Prod: Ed Guiney, Andrew Lowe

Cast: Brendan Gleeson, Don Cheadle

Laura Canning is a doctoral candidate and a lecturer at the School of Communications, Dublin City University. 


\title{
From Rural Electrification to Rural Pornification: Sensation's Poetics of Dehumanisation
}

\author{
Debbie Ging and Laura Canning
}

The opening sequences of Tom Hall's Sensation (2010) present a highly visual collision between traditional rural life and the global world of cybersex, in which the former is both symbolically and literally killed off. In the first of these powerful juxtapositions, a bucolic shot of sheep skipping over a ditch, (reminiscent of The Quiet Man), cuts to Donal (Domhnall Gleeson) masturbating with a porn magazine in a field. In the second, a jarring visual paradox occurs within the shot: Donal, on discovering his father dead in his stair chair, retrieves the remote control from the wall and activates the chair into tragic-comic slow motion down the stairs. Between the figure of (dead) father and son, the film's title appears in a lurid pink typescript beloved of 1970s soft porn. The superimposition of this incongruous font onto the shambolic rural kitchen scene, together with the symbolic spilling of seed on the land, annihilation of the father and drowning of the farm's kittens, establish a scenario in which not just paternal authority, but also nature and procreation, are brutally and unceremoniously extinguished and in which sexual pleasure and freedom can now presumably flourish. The miseries of the rural father-son relationship, so long the staple of Irish cinema, are swiftly obliterated and, when Donal returns from his father's funeral, the first thing he does is log onto an internet chatroom under the pseudonym 'sweetdick' to find himself a call-out prostitute.

While these oddly juxtaposed sex-and-death images make for an impressive start, Sensation as a whole is deeply unsure of what it is. Part black comedy, part social realism, the tone of the film hovers somewhere between the bleak, soullessness of American 'smart film' (Sconce 2002) and the self-knowing 'grotesquerie' (Attwood 2005) of Limerick hip-hop duo The Rubber Bandits and RTE's television series
Hardy Bucks. This marks a radical departure from Hall's previous work, which focussed almost exclusively on middle-class urban narratives (Bachelors' Walk, November Afternoon, Just in Time, Park) and demonstrated nuance, sensitivity and emotional insight in its dealing with difficult sexual topics, from rape and incest to the complexities of modern relationships. Sensation lacks this fine directorial touch, most notably in its conflicted - and ultimately dehumanizing - dynamics of spectatorial identification. It cannot be read simply as a comic black caper about two idiot bogboys and a hooker who set up a brothel, because the humour is based not on comic relief but on a desire to shock and transgress and, because of this, fails to lift the viewer from the underpinning ugliness of humanity that the film's grittier elements are simultaneously trying to portray. Nor, however, does it work as a critique of the emotional emptiness inherent in replacing one constraining set of realities (land, tradition and inheritance) with another (the use of pornography and prostitution to compensate for loneliness and lack of human intimacy) because, at some level, we are being asked to experience a level of empathy with Donal which is problematic; not just because he is a cold, misogynistic loser but for a number of other reasons, not least that the film cannot work to generate a scintilla of empathy for the male protagonists without necessitating the dehumanisation of the female characters.

Donal's alliance with New Zealand prostitute Courtney (aka Kim) - the first woman with whom he has ever had sex - becomes complicated when she is roughed up by men who are presumably pimps or customers, and accepts Donal's offer to stay at the farm. Even though this arrangement is no longer a commercial transaction, she stills feels compelled to service

ISSN 1699-311X 
him with a hand job, and from this point on, the lines of their relationship are constantly blurred as they clumsily negotiate the boundaries between being friends, lovers, client-prostitute and business partners. Unable to deal with the fact that Kim is still servicing other clients in their new joint business venture (an online-run brothel service which uses the domain names Limerick Ladies / Filthy Cows), Donal sleeps with local checkout girl Melanie while Kim is in hospital having breast implants and vaginoplasty to restore "honeymoon tightness" to her vagina, which she claims is like "a magician's sleeve".

When Kim returns from hospital, Donal's creepy friend Carl ("I love checkout girls. They're chicks that have to talk to you") is quick to exploit her suspicions about Donal, and offers to tell her everything in exchange for sexual favours. In this, the most overtly misogynistic scene in the film Carl leers at her bruised and bandaged breasts in a cruel and perverse enactment of the male gaze. Exhausted, still in pain from the operation, and upset about Donal's infidelity, Kim explains, "I can't have sex with you Carl, I've just had my vag done”, to which he replies, "You're still OK above the neck though". (The similarity of this with the scene in Pretty Woman (1990) in which Richard Gere's lawyer attempts to rape Julia Roberts' character, is striking in terms of how both mobilise a contrast between discourses of romantic courtship and those of sexual commodification in order to symbolically establish the male protagonist's ownership of the female protagonist.) On discovering that Kim has performed oral sex on Carl, Donal calls her a whore and orders her to leave the apartment, although he does concede that she can stay there "until you have those stitches out of your gash". Just as Donal's transformation from gombeen farm boy to slick, pony-tailed pimp is nearing completion, however, the brothel is raided by the Garda and Donal and Kim are arrested. In court, Kim is accused of masterminding the operation and conning Donal out of his money but, in the final scene, in which Kim visits Donal in prison, it emerges that he took the rap.

Whether the decision to represent the film's three prostitutes as 'foreign nationals' is intended to reference the sex industry's exploitation of migrant women or evades compromising the sanctity of Irish womanhood is unclear. What is more obvious is the male characters' apparent inability to treat prostitutes as real, equal people. Donal's expectations of Kim to be a friend, a lover or a prostitute depend entirely on his needs at any given time, and both he and Carl seem unable to understand that what she does for a living does not automatically make her sexually available to them at all times: if they've bought her once, they've bought her for all time. While $\mathrm{Kim}$ is seen to exert some power by virtue of the money she has persuaded Donal to invest and her superior worldliness (Carl reprimands him for taking orders from her and not behaving like a proper pimp), the film is insufficiently socialrealist in tone to mount a genuinely effective critique, either of the political economy of prostitution or of the dehumanisaton of women and sex that is shown to characterise the sexually repressed rural male psyche.

It is perhaps this treatment of the 'male psyche' that is the most chilling aspect of Sensation. While Carl is supposed to function as the villain to Donal's more benign character, they are almost indistinguishable. At one point Donal explains to Carl over a quiet pint in the local pub that his dreams are "like directing your own porn", and recounts in graphic detail a sexual fantasy involving cunnilingus between a mother and daughter, to which Carl enthusiastically responds, "You're some dirtbird, like a rapist inside your own head". In light of this, the framing of Donal's brief interlude with checkout girl Melanie as a conventional romantic failure, rather than the abusive act it is, rings hollow. That Melanie effectively has sex with someone else, not the 'Donal' she thinks exists, is a kind of sexual assault in itself. She seems to exist only to illustrate Donal's distance from convention and how much he has learned about how to impersonate normal human male behaviour/courtship. This may explain why Melanie, the only character who seems to have a reasonable perspective on the story ("It's all so fucking sordid"), cannot figure in the film for any longer than she does. The idea of men hiding base and violent 'natural' desires to degrade and dehumanise women behind entirely plausible exteriors is disturbing enough in a film such as Gaspar Noe's Irreversible, which exposes - and condemns - this in all its grim horror, but in a film in which we are being asked to laugh along with the protagonist, the disturbance is doubled and the viewer is left wondering, if the film is not expressly condemning the notion that Donal and Carl's perceived 'right' to ejaculate into any animal or woman trumps anyone else's right to 
remain unviolated, then what exactly is it doing with its spunk-or-die configuration of rural Irish manhood?

Given all this, the extent to which Donal's and Carl's social autism and underdeveloped sexuality can serve as a critique - whether serious or comic - of the paucity of Irish sex education (at one point Donal tells Kim that the only piece of sex education he ever got was from an uncle who told him that the most effective way to have sex with a sheep is to put its hind legs down the front of your wellies) is severely limited. Its attempts to engage the myth of the happy hooker are also compromised by its intermittent social-realist inclinations, such as when, Monica, frightened and alone, is taken by car to the apartment or when Kim recounts the sadness she experienced when she first had sex for money. In spite of this, Kim has no qualms about recruiting other inexperienced young women into the business and, in an unnerving subversion of the gaze economy of heterosexual porn, she asks Monica to strip so that she can peruse her body's suitability for male pleasure, and swiftly gets down to the practical business of getting her vagina shaved and her "butthole bleached". The prostitutes themselves seem conflicted about what has led them to this 'career choice', their obvious low self-esteem and lack of qualifications overlooked in favour of more deterministic accounts, such as Monica's claim that she has a high sex drive and Kim's recounting of her failed attempts to give it up.

There is an implicit message here that women enjoy or are addicted to their own subjugation, rather than any consideration of how lack of confidence and years of internalising their own sexualisation might have led them to prostitution. Nor are the men ever compelled to consider how they might feel if they were performing $69, \mathrm{BJ}$, deep throat, face-sitting, GFE, lap dance, outcalls, reverse, role play, tea bagging and uniforms (Kim's / Courtney's repertoire of services as advertised on her webpage) and cosmetically reconstructing their bodies for living. This is reinforced by the way in which the film's own gaze economy replicates rather than critiques or subverts the gaze economy of straight male porn, lingering on and eroticizing the naked female bodies but never those of the men. The sex industry is configured as a dirty but level playing field in which women give as good as they get, exerting that quintessentially postfeminist conceptualisation of power which hinges upon women manipulating men's desire. Meanwhile, the power dynamics of porn-inspired hetero sex and the macro political economics of the industry don't feature in the sense that they are naturalised / invisible.

At best then, Sensation is a film about failure (Donal's sexual inability, which can only be overcome by subjugating others, his failed entrepreneurial adventure, and the final ignominy of being recuperated back into his, explicitly female-dominated, extended family) but the bigger failure is its sheer lack of clarity as regards how it wants its audience to feel. Perhaps, as appears to be the case with many contemporary Irish films, it never really had female spectators in mind? Because it shies away from the uncompromisingly bleak, 'smart' (Sconce 2005) tone of satirical American films such as Todd Solonz' Happiness (1998) and Neil LaBute's Your Friends and Neighbours (1998) or the gritty social realism of British films like Stephen Frears' Pretty Dirty Things (2002), the naïve plot-related moralism of the story - Donal shows that he really cares for Kim by going to prison, and is thus punished for his transgressions - can never recuperate its darker messages about male heterosexuality. In 2008, Mark O'Halloran commented in a special issue of Film Ireland on sex in Irish cinema that there had yet to be an erotic Irish film (O'Halloran 2008: 5). Sensation is almost certainly the most sexually explicit Irish film made to date but it is entirely devoid of eroticism and as such it bears out Fintan Walsh's claim that joyous, erotic, guilt-free sex remains conspicuously absent on the Irish screen:

... sexuality is curiously central to Irish film. Curious in the sense that it often functions as a highly symbolic device that shapes and critiques the ostensible world represented; more curious still in that it is a sexuality generally devoid of energy, feeling and eroticism. Viewed against the arthouse outputs of our European neighbours, for example, there is little in Irish film to match the easy sexiness of Fellini's work, the latent carnality of Buñuel's or the libidinous charge of Breillat's (Walsh's 2008: 16). 
By contrast, there is nothing sensuous or sensational about this film, which parlays its faux-titillating title into a loathsome froth of masculine inadequacy and deep-seated misogyny.

\author{
Sensation (2010) \\ Dir: Tom Hall \\ Prod: Kieron J. Walsh \\ Cast: Domhnall Gleeson, Luanne Gordon
}

\section{Works Cited}

Attwood, Feona. 2005. “Tits and ass and porn and fighting': male heterosexuality in magazines for men”, International Journal of Cultural Studies. 8 (1), pp. 83-100.

O’Hallorhan, Mark. 2008. “Sex please, We’re Irish” Film Ireland, 120, Jan/Feb, p. 5.

Sconce, Jeffrey. 2002. “Irony, Nihilism and the new American 'smart’ film” Screen 434 Winter.

Walsh, Fintan. 2008. “Cock Tales: Homosexuality, Trauma and the Cosmopolitan Queer. Film Ireland 120, Jan/Feb, pp 16-18.

Debbie Ging is Chair of Film and Television Studies at the School of Communications, Dublin City University. Her book on Men and Masculinities in Irish Cinema will be published by Palgrave in 2012.

Laura Canning is a doctoral candidate and a lecturer at the School of Communications, Dublin City University. 


\section{Ballymun Lullaby}

Denis Murphy

Music oft hath such a charm

To make bad good, and good provoke to harm

(William Shakespeare)

It is with the positive side of this equation - the healing, redemptive power of music - that director Frank Berry's documentary feature debut is concerned. The film documents the efforts of Ron Cooney, a music teacher whose affable demeanour masks a fierce determination to enrich and transform the lives of the young people of Ballymun. This is no simple task in an area that has become synonymous with social deprivation in Ireland; a quick-fix, system-built experiment that became the worst planning disaster in the history of the State (McDonald 2010: 250). Now, to mark the area's redevelopment, a choral-orchestral musical suite is commissioned. This provides Ballymun Lullaby with a natural story structure as the eponymous suite is rehearsed, recorded and performed by Cooney's young students in collaboration with composer Daragh O'Toole, conductor Frank Brophy, and the RTE Concert Orchestra.

A succinct, tightly edited opening sequence sums up the brief history of the notorious Dublin estate. Ballymun's creation, in response to severe housing problems in Dublin's overcrowded inner-city tenements, is presented via archival footage as "a bold, daring and ambitious attempt to serve a desperate need in the capital city". The initial optimism is quickly undermined, however. Sparse recreational amenities, inadequate shopping facilities, and poor housing maintenance combine to create a suburban ghetto where unemployment, crime, drugs and so-called anti-social behaviour become the norm. Less than forty years after it began, the high-rise experiment ends. The estate is redesigned on a lowrise human scale, and in a powerfully symbolic moment, the maligned towers are brought crashing to the ground. It's a bittersweet moment for Ballymun residents, for whom the towers, for all their attendant social problems, represented community, youth and home.

Berry (who is credited as producer, director and editor) constructs Ballymun Lullaby around a series of interviews interspersed with music rehearsals, archive footage and landscapes. The major contributions come from Cooney and three of his young charges: multi-instrumentalist Tara, lyricist Darren and singer Wayne. Cooney's notable ability to communicate with and inspire his students is illustrated in a number of exchanges. His apparently boundless optimism seems to prevent him from voicing any negative thoughts: he is obliquely critical of the education system, but when he starts talking about promising students lost to the dubious priorities of adolescence, he is unable to complete the sentence. Later, a brief allusion to a health problem underlines his tireless dedication to his work, which he describes simply as "to engage the children through the medium of music". Tara, Darren and Wayne's contributions, meanwhile, leave the spectator in little doubt about the value of this engagement in their own lives.

It is tempting, given the theme of urban regeneration, to reflect on parallels between Ballymun Lullaby and the GPO Film Unit's Housing Problems (Elton and Anstey 1935), another film that "uses the actual voices of those involved in the situation to create a 
warm, convincing account of people working together to reverse decay" (Barsam 1992: 109). The inclusion of these voices was considered radically innovative at the time, although the associated formal device, the 'talking head' which evolved into standard practice in television journalism, has become sufficiently hackneyed that its use in documentary film is sometimes derided as unimaginative (Sarkar and Walker 2010: 2). Berry's innovation is to shoot many of his interviews on the move, in a series of outdoor travelling shots that depart from the carefully composed static tableaux that otherwise dominate Ballymun Lullaby's gaze. Berry has claimed that this decision was taken to overcome the stilted nature of the studio interviews he had originally taped with his subjects (SDGI 2011). Whatever the provenance of the creative decision, Berry's 'walking heads' become a striking feature of Ballymun Lullaby, firmly locating his subjects within the threedimensional space of their everyday environment. These shots also illustrate starkly the unfinished nature of the Ballymun regeneration project, as the moving camera repeatedly reveals the extent of waste ground and dereliction that forms the physical backdrop to the protagonists' lives - a liminal space between the old and the (as yet unfinished) new Ballymun. Berry also allows some verité-ish ruptures as these filmed walkabouts are repeatedly interrupted by passing pedestrians and motorists, drawing attention to the documentary artifice, perhaps, but also to the vibrant - and occasionally vaguely threatening - nature of street life in the vicinity.

Ballymun Lullaby has its roots in a series of voluntary community video productions in which Frank Berry and videographer Kevin Duffy had participated, and indeed the project commenced along those lines. The film was shot on standard definition digital video on a no-budget basis after Berry and producer Joanne O'Hagan were unable to find funding for a television document- tary on the Tower Songs project (SDGI 2011). An eventual award of $€ 60,000$ in completion funding from the Irish Film Board was spent on sound mixing and picture grading, bringing the film to a suitable technical standard for festival exhibition and, eventually, theatrical exhibition in Ireland. ${ }^{1}$ The film was enthusiastically received at the major Irish film festivals throughout 2011, leading to a pre-Christmas theatrical release. Berry also won the Screen Directors Guild of Ireland's Director Finder Series award, leading to a showcase Hollywood screening in front of US film distributors and other key industry players.

At the time of writing, however, no US distribution deal has been announced, and despite its festival success in Ireland, perhaps television is a more natural home for Berry's film, especially given the necessarily limited scale of its cinematic ambition. The film has already been shown in Ireland on RTE television, where it has marked a refreshing change from the frequent articulation of community and arts involvement within halfhour 'factual programming' formats, often fronted by minor celebrities with little or no natural connection to the subject matter. In contrast to such presenters, Ron Cooney, his students, and the rest of the real people populating Ballymun Lullaby's frame seem more genuine, more dedicated, and frankly more interesting.

\author{
Ballymun Lullaby (2011) \\ Director: Frank Berry \\ Producer: Joanne O’Hagan, Frank Berry
}

\begin{abstract}
1. The Irish Film Board website lists this funding as a documentary production loan (IFB 2012). It is clear from Berry's account, however, that the film had been largely completed at this stage and that the funds were spent on post-production activities more normally associated with completion funding (SDGI 2011).
\end{abstract}

\section{Works Cited}

Barsam, R.M. 1992. Nonfiction film: a critical history. Bloomington and Indianapolis: Indiana University Press. 
Housing Problems 1935. [DVD]. Directed by Arthur Elton and Edgar Anstey. UK. British Commercial Gas Association

McDonald, F. 2000. The construction of Dublin. Cork: Gandon Editions

Sarkar, B. and Walker, J. 2010 (eds). Documentary Testimonies: global archives of suffering. New York and London: Routledge

SDGI 2011. SDGI Podcast. Frank Berry on Ballymun Lullaby [Online], 12 December. Available from: http://www.sdgi.ie/news/sdgi-podcast.php [Accessed 9 March 2012].

Denis Murphy is a doctoral candidate and lecturer at the School of Communications, Dublin City University. He has also worked as a film producer and editor for more than two decades. 


\title{
Ballymun Lullaby: Community Film Goes Mainstream
}

\author{
Eileen Leahy
}

The Dublin suburban area of Ballymun can be considered as having attained iconic status in Irish culture. Developed in the 1960s in response to a continuing housing shortage, it was Ireland's only high-rise public housing project and was "heralded as a symbol of the New Ireland", embodying progress and modernisation (Nexus Research Co-Operative 2008: 4). Ballymun subsequently became synonymous with deprivation, and its decline came to mark our disillusion with progress (Norris 2001: 3-4). As the country experienced the Celtic Tiger boom, Ballymun was scheduled for urban regeneration through a public-private partnership, a project that captured the national imagination, perhaps as a symbolic image of the regeneration of Ireland as a nation, encapsulating our hopes for an end to poverty and social exclusion. To date 28 of the 36 tower blocks have been demolished, the remaining due for demolition by 2014, and building of new housing continues (BRL 2011). The regeneration scheme, run by Ballymun Regeneration Limited (BRL), has created a new town in Ballymun with retail centres, neighbourhood and community centres, arts, leisure and recreational activities.

Ballymun has featured prominently in Irish national cinema, emblematic of urban alienation and disadvantage. As a location in mainstream and commercial cinema, the area has been prominent in film and television dramas that draw on a gritty urban aesthetic. ${ }^{1}$ In addition

1. For examples see Pigs (Cathal Black, 1984), The The Commitments (Alan Parker, 1991) Family (Michael Winterbottom, 1994) and Scene (Charles McCarthy, 1996). It is also the urban setting for Into the West (Mike Newell, 1992), and is a key location in Adam and Paul (Lenny Abramson, 2004). factual film and documentary have repeatedly focused on Ballymun as a site of urban disadvantage. ${ }^{2}$ Facts of Life (RTE, 1987), for example, looks at drug problems in Ballymun, whilst the profile of Dublin, In Flags or Flitters: Pictures of Dublin (Donald Taylor Black, 1991), used Ballymun to counterpoint more romantic depictions of the city. More recently, reality programming such as Des Bishop: Joy in the Hood (RTE, 2006), continued this association of Ballymun with deprivation. The regeneration of Ballymun has also featured prominently in Irish cinema, the documentary No More Tall Stories (RTE, 2004), for example, focuses on the regeneration of this area, while the experimental film, Hereafter (Paddy Jolley, Inger Lisa Hansen and Rebecca Trost, 2005), explores the derelict spaces of unoccupied tower blocks in Ballymun. Thus the on-screen representation of Ballymun constructs the area as one of urban decay and social deprivation, albeit with the more recent twist of the possible alleviation of these issues through regeneration.

In this context it is interesting to look at films that emerge from within Ballymun itself, made by or with a local community that live in the area, rather than from an outside agency or filmmaker. Community film refers to films made by local communities, usually through collaboration or participation with a filmmaker, although increasingly community films are being made without any professional filmmaking input.

2. Current affairs programming on national television provides many examples. Seven Days (RTE, 1973), Today Tonight (RTE, 1987), Evening Extra (RTE, 1987), and Cogar (TG4, 2002), to name just a few, have all featured Ballymun as representative of social issues associated with public housing. 
A number of community films have emerged from Ballymun from the 1980s to the present including Two of $a$ Kind (Ballymun Development Co-Op) from 1986. In addition, Irish cinema's new wave of the 1980s often blended community practices and approaches with more mainstream conventions, and we see this community film ethos in One Day Time (Joe Lee, 1982) and Sometime City (Joe Lee, 1984).

Community film has continued to be important for Ballymun through an eclectic mix of many and diverse forms. There are simple filmed documentaries and reports of community activities, made by and for the local communities involved, such as the short documentary Orchestrate Workshops in Progress (axis Ballymun, 2011) reporting on one of the Ballymun Music Programme's community arts projects. There are also collectively and individually authored documentaries about Ballymun communities and Ballymun life. Is Anybody Listening (Solas Development Centre and Ballymun Partnership, 2005) and the mockumentary, Bag of Bags (Dogmedia, 2006), are two examples. There are artist films like Leisure Centre (desperate optimists, 2005), and promotional films such as Get Connected (Peter Kelly and Jigsaw, 2010), which was made for Mental Health Week 2010. Ballymun communities have also made comedy films like Little Mun (Trinity Comprehensive School, 2006) and music videos like Products of the Environment by Street Literature (Ballymun Communications, 2010) or drama such as Tower Tales (Ballymun Communications, 2010), as well as a range of films that are experimental in their content, style or form. Into this mix comes Ballymun Lullaby, the 2011 feature documentary from director Frank Berry, winner of the Directors Finders Series 2011 and nominated for a 2012 IFTA, Irish Film and Television Award. This film tells the story of a "Tower Songs"” music project led by the Ballymun Music Room's music director Ron Cooney. In this project composer Darragh O’Toole works with a

3. Tower Songs is a long-term, citywide, community arts project, led by CityArts, where musicians collaborate with youth and community organisations in Dublin to express their experience of urban regeneration and development. group of young people to compose a piece of music, which is then performed by the young people with the RTE Concert Orchestra. The documentary follows this music project through composition and rehearsals to the making of a CD recording.

Director Frank Berry describes his document community cinema because of its roots i involvement in community filmmaking in Ballymı a number of years, directing community film themes as diverse as "educational opportunities, pr development, disability and social disadvantage" 2011). Whilst Ballymun Lullaby has not been through the usual community film channel processes (a community development objective a use of participatory production processes, for exc it nonetheless straddles the divergent approac commercial and community cinemas, though is firmly rooted in the latter tradition.

The film opens on archive footage of the civil unrest and demonstrations about poor and inadequate housing in Dublin that led to the development of Ballymun. Archive television and online video footage shows the progression of Ballymun from a symbol of progress to an emblem of social disadvantage. In this way it aligns itself with a community film ethos, by providing a social, economic and political context for the deprivation experienced in this community. There is also movement between the different locations within Ballymun, of school, home, music room and Axis Arts Centre, as well as a variety of shots of the area, which firmly defines this as a place-based community. Although the film mainly focuses on an individual teacher and three of the teenage participants in the project, the film also emphasizes that the music project is a collaborative effort with large groups of younger children practising and performing together. Children feature prominently throughout the film, but they are seen en masse, avoiding the potential for their exploitation. In addition the film eschews heart-wrenching stories of triumph over adversity, common to commercial film and television dealing with stories from disadvantaged urban locales.

However, Ballymun Lullaby relies on many of the conventions of popular and commercial documentary more often than is usual in community film. It focuses in depth on music 
director Ron Cooney. His eccentricities and idiosyncrasies are highlighted, and the film demonstrates his passion and commitment to music in interviews, footage of him teaching, rehearsing and facilitating music with the youngsters and of him moving frantically from one class or session to another. His dedication is also foregrounded through talk of a heart attack and of how he has kept going despite medical problems. This presentation of Cooney mirrors the narrative strategies of dominant media, in which transformation, success or glory comes through the charismatic, workaholic and singleminded personality of an exceptional individual, rather than as a result of collective action. As Cooney himself pointed out ${ }^{4}$ Lullaby gives the impression that he alone drives the Ballymun Music Room, but the reality is that there are more than thirteen music teachers involved in delivering the range of music projects on offer there, as well as contributing to this particular project. So, despite its uplifting message that young people from Ballymun are full of potential and ability, the film posits that the realisation of this potential and ability ultimately depends on the drive and commitment of one exceptional individual.

The film also constructs this particular project as an exceptional, once-off opportunity for a group of disadvantaged children. In reality the Ballymun Music Programme have been running comparable projects over a number of years, with a number of similar success stories. Indeed, Berry's 2003 Fanfare for Ballymun film covered the same territory, a renowned composer works with a group of secondary school children on a composition that is then performed by the participants. 'Fire', the music composition featured in Fanfare, went on to be recorded by BBC Northern Ireland and a CD was released. Thus, despite its construction in Lullaby as a unique and extraordinary event, the music project at the heart of the film is part of a regular and on-going series of projects.

Lullaby also uses mainstream narrative devices to create tension and drama. Berry originally set out to film a year in Ron's life at the Ballymun

4. At a Question and Answer session after the film's release at the Irish Film Institute, Dublin, on $16^{\text {th }}$ December 2011.
Music Room, but switched focus to cover this particular project happening there, from its inception to completion in a recorded CD. The filmmaker chose to provide this narrative trajectory for the film, with a goal for the participants to reach a target of sales for the CD. Such a target is not part of the remit of the Tower Songs participatory project in itself; its aim is primarily to promote participation in socially engaged arts practice within the communities in question. The drive to reach this goal, therefore, is constructed within the film in order to provide the tension necessary to keep an audience rooting for the main characters. Whilst this dramatic suspense makes the film narratively compelling it also undermines the real achievements of the project. The significance of the successful collaboration between young people and composer and then conductor, the accomplished performances and the extraordinary musical talents that these young people display throughout the film is potentially undermined because the CD did not reach its target sales.

At the same time, the film does provide a powerful counter to dominant media constructions of musical talent and success. One example can be found in the contribution by the project's soloist, Wayne Beatty, who was previously a contestant on the UK hit television programme, The X Factor (ITV, 2004 -) in 2006 and on a similar Irish programme Class Act (RTE, 2007- 2008) in 2007. Lullaby presents Beatty as a young adult who is struggling to live up to the failed promise of these talent shows, receiving hate mail and enduring bullying because of his participation in these contests, which lack the back up and support that community-based music projects provide.

The film creates a strong contrast between Beatty and the other two music participants it features. Tara O’Brien is presented as a serious musician who has been a student of Ron's for years. She is shown practicing assiduously, having achieved a scholarship to DIT's music conservatory. ${ }^{5}$ She is not someone who looks to music to provide her with fame and fortune. Her

5. The Dublin Institute of Technology, Conservatory of Music and Drama. [Available at: http://www.dit.ie/conservatory/] 
ambition involves teaching and giving back to the community who provided her with her music education. Similarly, Darren Scully, a young poet who provides the lyrics for the piece, is shown to be interested in this work as creative expression rather than as a route to fame. This highlights the difference between the commercial aspirations of mainstream music industries and the realisation of real musical education in the work of the Ballymun Music Programme and Music Room. The film posits that community music projects are not about fame and money, but about personal growth, educational development and collaborative creativity. Thus it uses the conventions of dominant mainstream media to show how its alternative - participatory and community arts - work in practice.

Ballymun Lullaby (2011)

Dir: Frank Berry

Prod: Frank Berry

Music: Daragh O’Toole

\section{Works Cited}

Breaking Ground. 2005. “Elaine Agnew, Ron Cooney and the Ballymun Windband Project.” Artists. Breaking Ground. http://www.breakingground.ie/artist.asp?id=57\&section_id= [accessed 25 January 2012].

BRL, Ballymun Regeneration Ltd. 2011. “Regeneration Update.” What’s New. http://www.brl.ie/wnew.htm [Accessed 25 January 2012].

Berry, Frank. 2011. “Ballymun Lullaby: Community Cinema.” Irish Film Institute Blogspot. Irish Film Institute. 13 Dec. http://irishfilminstitute.blogspot.com/2011/12/ballymun-lullaby-community-cinema.html [Accessed 25 January 2012].

Nexus Research Co-Operative. 2008. A Local Anti-Poverty Framework for Ballymun. Dublin: Ballymun AntiPoverty Network.

Norris, Michelle. 2001. "Privatising Public Housing Estate Regeneration: A Case Study of Ballymun Regeneration Ltd., Dublin” [Online]. Paper presented to the joint Irish Social Policy Association/Social Policy Association Conference: 'Development, Regeneration and Social Policy'. $26-28^{\text {th }}$ July 2001, at Trinity College Dublin.

Eileen Leahy is researching Community Filmmaking in Ireland, for a Ph.D., at Trinity College Dublin, funded by the Irish Research Council for the Humanities and Social Sciences. 


\title{
The Other Side of Sleep (2011)
}

\author{
Tony Tracy
}

Beyond the abnormally high instance of male crises narratives that dominate recent Irish film output (Parked, Savage, Sensation, Rewind, The Guard,) and genre cycles (notably horror) IFB/RTE funding has in recent years facilitated the emergence of a heretofore underexplored setting that has been absent and even reviled by Irish audiovisual media: the midlands. This is a broad church ranging from Garage, Eamon, Eden, the creative documentary His and Hers and the TV series Pure Mule. To this list we can now add Rebecca Daly's confident debut feature The Other Side of Sleep. A defining characteristic of these midland narratives is their contemporary setting in towns outside of the traditional rural / urban axis which take Ireland's interior as an expressive setting of indeterminacy and transition, albeit in often quite different ways. Stylistically they deliberately depart from the tourist gaze tradition of Ireland on film or generic conventions in an often meditative perception of landscapes and a built environment that is hodgepodge, unremarkable and all too familiar. In Lenny Abrahamson's Garage (2007) the unworldly lead character Josie searches in all the wrong places for a connection to his surroundings only to find himself shamed, fired and evicted. Presented in a series of vignettes that emphasize the small routines of Josie's life, the Irish small town, superficially a secure setting of close relationships and familiarity is imagined instead as a location of isolation and fragile networks; the garage in which he lives a make-shift home that externalizes his temporary and insecure status. Gerry Stembridge - attentive to the social resonance of Irish locations in films like Guiltrip (1995) and About Adam (2000) offers in Alarm (2008) a portrait of a commuter development on the edge of a small town that is an unstable space of paranoia and foreboding. Structured around successive weekends, the drama of RTE's TV series Pure Mule (2005-) similarly pivots on an uncertain dynamic of stasis and change; the frustrations of small town life give way to routine escape into alcohol and the eventual decision of two characters to leave definitively and emigrate. The imaginative and very popular His and Hers (2009) also structures its trans-generational portrait of Irish women as a cyclical narrative but in a very different register; its midlands setting corresponding to the transitional, intermediate nature of life itself; a space between.

The Other Side of Sleep continues this spatial consciousness of the Irish midlands as an intermediate zone in a new and eerie configuration: between sleep and consciousness. More precisely, it imagines this midlands setting as an expressive site of trauma. The often oblique narrative centers on Arlene Kelly (Antonia Campbell Hughes) a young factory worker who is prone to sleepwalking and a plot triggered by the mysterious murder of a young girl, discovered by Arleen during one of her night walks.

Although described as a thriller, the film's dream-like tone and structure dampens any straightforward emotional engagement. Daly and co-writer Glenn Montgomery eschew narrative clarity in signaling what scenes we are to read as memory, sleepwalking or the conscious present. This oneiric shuffling of memory and events is a powerful conceit, reminiscent of European rather than American explorations of the theme. In a displacement familiar from the early films of Atom Egoyan, Arlene's muted, somnambulant response to the girl's death is linked to the personal trauma of her mother's disappearance 
when she was a young girl. In Freudian terms, the problem of trauma is a problem of narration, the conscious and unconscious in troubled, intermittent and fitful communication and so it is here. This theme is counter-pointed with a naturalist, albeit elliptical style of storytelling that recalls French regional film-making (the films of Bruno Dumont for instance); a style linking the narrative's subjective and geographic de-centering. We find ourselves trying to position ourselves within the narrative, to identify what is of significance and what is merely banal and quotidian. Of course, the quotidian is immensely significant; providing rhythm and coherence to an existence that has experienced a devastating and potentially irreparable interruption. The setting adds immeasurably to a sense of everyday routine, particularly the early scenes set in the factory where Arlene works. One is struck in these scenes by the rarity of images of factories in Irish cinema, as well as the sense of community among its female work force, which includes the striking presence of actress Olwen Fouéré (in a minor but forceful role as the mother of the boy accused of the murder). An especially strong image here relates to Arlene's machine work, juxtaposing her semi-conscious, out-of-body state with very real physical dangers. This physical vulnerability connects her with the murdered girl, foregrounding a feminine subjectivity that is all too uncommon in Irish film.

Arlene is seen progressing through a series of unsuccessful encounters with others that reflect her fragile psyche. Her boss seems attracted to her, and although she does not reciprocate, he tries to offer her a lift home but she flees without explanation. She befriends the dead girl's sister and seeks proximity to the family's grief only to be repudiated as a stranger by the mother. Likewise she displays an uncertain and impassive response to attempts at physical intimacy from the girl's boyfriend. In all of these situations Arleen has a spectral quality in which the body and consciousness do not connect. The effectiveness of this tension between presence and absence depends on a delicate and balanced performance of Antonia Campbell Hughes who occupies practically every shot of the film. In the hands of a lesser performer we might quickly tire of the narrative's unannounced slippages but Hughes manages to convey a sustained combination of engagement and estrangement with proceedings, ensuring the viewer always remains curious and concerned.

Along with this compelling central performance The Other Side of Sleep maintains its delicate tone through Daly's strong eye for composition, lending the film an aesthetic sensibility that breaks through the everyday surroundings with often striking imagery to suggest a struggle for coherence and harmony. Especially notable is a repeated image of a treelined avenue that interrupts the featureless midlands landscape. The image is a utopian landscape of natural harmony to parallel the journey back from grief that Arlene and the dead girl's family have embarked upon.

The Other Side of Sleep (Irl 2011)

Director: Rebecca Daly

Writers: Glenn Montgomery, Rebecca Daly

Cast: Antonia Campbell-Hughes, Sam Keeley and Olwen Fouere

Tony Tracy lectures in Irish, American and Silent Cinema at the Huston School of Film and Digital Media, NUI Galway where he is course director of the BA with Film Studies. 


\title{
A Changing Subject-Position for Travellers in Knuckle (Ian Palmer, 2011)
}

\author{
Eileen Leahy
}

Irish Travellers are an indigenous minority group that have been marginalised and excluded in Irish society (Bancroft 2005: 42-44). Their prominence in moving image production belies their marginal status in Irish society and it can be argued that Travellers have taken on a symbolic role for the general public in Irish culture. Travellers have featured in Irish cinema throughout its history in both indigenous and diasporic productions, such as the British productions No Resting Place (Paul Rotha, 1951) or Snatch (Guy Ritchie, 2000). Travellers in indigenous Irish cinema often signify Ireland's 'Other', denoting an outsider status and issues of exclusion, and at other times creating a microcosm of Irish society through the depiction of Travellers' rich heritage and tradition under threat. Irish films such as Traveller (Joe Comerford, 1981), Into the West (Mike Newell, 1992) and Trojan Eddie (Gillies MacKinnon, 1996) construct Travellers as romantic figures linked to Ireland's pre-modern past, representing Ireland's confused post-colonial identity and indicating an alternative to official discourses of Ireland and Irishness (McLoone 2000: 134-5, Barton 2004: 185-6, Pettitt 2000: 129, 272).

Ian Palmer's 2011 documentary Knuckle is interesting because it challenges this subject position of Travellers in Irish film. The film was shot over twelve years as Palmer immersed himself in the "underground" scene of bareknuckle boxing among a particular Traveller family, the McDonaghs, and the film presents the viewer with an insider view of this secret world. ${ }^{1}$ However, the Travellers themselves have a

1. See www.knucklethemovie.com for trailer and promotional material, which highlights a privileged and exclusive insight into a secretive world. different perception of the film and the filmmaker's relationship to his documentary subjects. According to Palmer (Interview), "they saw it as their film”, a perception repeated throughout the film as they comment on the documentary being made. A fuller understanding of this changing subject position can come from an understanding of the context in which the fights were filmed.

Film and video have been an integral element in Traveller bare-knuckle fights in recent years, since technological developments in film equipment allowed the practice of filming fights to become widespread. Bare-knuckle boxing is part of a Traveller tradition of settling disputes through a system known as "Fair Play". This system of conflict resolution is important in Traveller communities because of mistrust of the police and of the criminal justice system, which operate within a social order that discriminates against Travellers. In the Fair Play system two opponents, representing both sides of a dispute, settle the disagreement through a structured fight, under strict rules and with the supervision of disinterested third-party referees. The outcome of the fight is binding on all involved, and the dispute is settled in favour of whichever side the victor represents. Usually the disputes are between families, and the fighting is not just about a conflict or dispute, but often a matter of preserving the family's honour.

Filming serves important functions in the Fair Play system, in that a record of the fight is available so that outcomes cannot be disputed. Videotapes from the early days of filming fights, and latterly DVDs, are watched in groups after a fight has taken place. Usually the family or group involved in the feud are not able to attend the fight, for reasons of security, because of the

ISSN 1699-311X 
underground nature of the fighting and because the Fair Play rules don't allow the group to attend in order to prevent more widespread fighting from developing. The filmed footage of the fight serves as proof that the dispute was settled through the fair fight system. As filming of fights developed, the various groups involved in a dispute would each have their own "videoman" recording the contest. These recordings are watched by all involved and often have a life of their own after the dispute has been settled. They can be viewed as sporting contests and used by fighters as part of their training for a bareknuckle contest. Film and video footage of fights have thus become commonplace and, in recent years, are increasingly being posted online.

Thus the filmed footage in Knuckle can be viewed as more than simply Palmer's own filmed footage for his documentary. From the Travellers' point of view he was the video-man on one particular side of the dispute, usually the McDonagh side, and parts of the film show found footage from other video-men. Palmer didn't necessarily see his own role as such, but accepts that an exchange took place where the Travellers allowed him access in exchange for the use of his footage in this way, so that he came to be seen within the community as the McDonagh's video-man (Interview).

In addition to the film footage of the actual fights, challenges to a fight are also filmed and some of these are included in Palmer's documentary, both as found footage and filmed by him. Filmed challenges can be a part of the bare-knuckle process, in which one member of a family involved in a dispute might challenge a member of the opposing side to fight, through sending him a DVD of the challenge. These are highly stylised performances and all take a broadly similar form, where a challenger will brag about his superiority, list his grievances or accuse the challenged opponent of some misdeed, often calling upon the honour of his family in the process. In many cases a response to the filmed challenge is made where counter claims are made by the potential opponent. Again, filmed challenges are viewed within the Traveller community and are widely available online. It can be argued that this highly innovative use of film within an indigenous community presents not only the use of film as a form of folk memory, but also an interesting insight into alternative uses of film, alternative audiences and alternative approaches, that would be worthy of a more detailed exploration than this review allows.

However, it is important also to acknowledge that the practice of bare-knuckle boxing and the filming of contests or challenges can be a very contentious issue among Traveller groups and organisations, and in the Traveller community, and the response from many Travellers to the film has been negative. At a panel discussion accompanying the release of Knuckle, ${ }^{2}$ Traveller members of the audience took Palmer to task for his negative portrayal of this community. Individual Travellers and representatives from the Traveller community voiced their concerns at the negative stereotypes being promoted in this documentary, as well as at this film's contribution to the distortion of the Traveller tradition of Fair Play. Some of those in the audience argued that the culture and tradition of fair fights was not focused on fighting but on fair play, but that media attention has glorified the fighting over other elements, with negative consequences for Travellers and for the practice itself, which has been transformed from a system of conflict resolution to a mere competitive sport through these media interventions. As a Traveller Interagency Report (2011: 5) points out, the traditional fair fight system has recently diminished in its ability to achieve binding results

2. To coincide with the release of Knuckle, the Irish Film Institute (IFI) presented a programme of fiction and non-fiction films sympathetic to Travellers, from the $6^{\text {th }}$ to the $7^{\text {th }}$ August 2011, including No Resting Place (Paul Rotha, UK, 1951) which highlights the negative effects of discrimination, Traveller (Joe Comerford, Irl., 1981) which provides an in depth portrait of a young Traveller couple, Southpaw (Liam McGrath, IRE/UK, 1998) a documentary about Olympic boxer Francis Barrett and Pavee Lackeen (Perry Ogden, 2005) a blend of documentary and drama that shows the live of a young traveller girl. Accompanying this programme was a panel discussion entitled "Framing Travellers" on August $7^{\text {th }}$, 2011, with Knuckle's director Ian Palmer and the director of Southpaw, Liam McGrath as well as representatives from the Traveller community, Michael Collins, actor and writer and Catherine Joyce, community development worker. 
among the community because betting on fights and posting videos of fights on the internet "has altered [the] purpose" of fair fights. Palmer would argue that money is not of real significance in his experience of the contests and that honour and family loyalty remain the primary motivators (Interview). However, it is noteworthy that his film draws attention to an exchange of money on a number of occasions, thus questioning the combatants' motives for the fight.

The film should be understood in the context of a broader media construction of Irish Travellers. Its release coincided with a burst of negative or exploitative media representations of Travellers in general, both in Ireland and in the UK. This film entered the public realm as a major on-going eviction of Irish Travellers from an unauthorised site at Dale Farm in Essex had been attracting a lot of media attention in the UK and Ireland. It also overlapped with the success of the immensely popular television series Big Fat Gypsy Weddings (Channel 4, UK, 2011), which gained the highest ratings for Channel 4 in recent years and which is now in its second series. Big Fat Gypsy Weddings has not been well received by either Travellers or by Roma Gypsies in the UK and in Ireland (Bowers 2012). In Ireland television shows such as TV3's The Truth About Travellers (IRL 2010) also gained high ratings and despite attempting to provide a balanced insight into Travellers' lives were also arguably somewhat exploitative in their approach. At the same time as representations such as these dominated the media in general, Traveller rights and community organisations have been campaigning to have their status as a distinct ethnic group recognised in Irish law.
Such a status would mean that they would be provided by the state with additional resources to ensure their protection, including protection from harmful media representations. As yet their ethnic status has not been officially recognised by the Irish state, though it is recognised in the UK, and at the UN's Universal Periodic Review last October, the Irish government indicated that consideration is being given to recognising ethnic minority status for Travellers (Irish Traveller Movement 2011: 1-4). The voyeuristic and exploitative nature of much media attention serves to reinforce the marginality of Travellers as different and "other" without allowing them to be recognised as different enough for equal treatment as an ethnic minority.

Palmer gets around some of the issues of negative stereotyping, of prurient interest or exploitative and voyeuristic representations, by constructing a very subjective and personal account of his own journey over a number of years into what for him was an alien world. By adopting this subjective stance the film questions his almost obsessive interest in the practice of bare-knuckle fighting among Travellers and thus challenges viewers to question their own interest in, and attitudes to, the Travellers who live by those rules. By highlighting the Travellers' own involvement in filming the fights it also presents viewers with an opportunity to rethink how communities can represent themselves. Knuckle ultimately shows that Travellers have begun this process of self-representation, within their own traditions and their own culture, and in forms that might not be amenable to mainstream consumption without the mediation of filmmakers, from the settled communities, such as Palmer.

\section{Works Cited}

Bancroft, Angus. 2005. Roma and Gypsy-Travellers in Europe: Race, Space and Exclusion. Aldershot: Ashgate Publishing Limited.

Barton, Ruth. 2004. Irish National Cinema. London: Routledge.

Irish Traveller Movement. 2011. "Strongest Signal Made by Irish Government to Recognise Travellers as an Ethnic Group”. Press Release. Irish Traveller Movement. $6^{\text {th }}$ October. Available from: http://www.itmtrav.ie/uploads/Traveller_Ethnicity_News_Release_6_Oct_2011.pdf [Accessed 08 February 2012].

McLoone, Martin. 2000. Irish Film, the Emergence of a Contemporary Cinema. London: British Film Institute.

Palmer, Ian. 2012. Interview. 11 February. 
Pettitt, Lance. 2000. Screening Ireland, Film and Television Representation. Manchester: Manchester University Press.

Traveller Interagency Programme. "Working Towards Peace: a Report on the Midlands Traveller Conflict and Mediation Initiative.” Traveller Interagency Programme 2011. Available from:

https://www.pobal.ie/Funding\%20Programmes/traveller/Documents/WorkingTowards\%20Peace\%201.pdf [Accessed 08 February 2012].

\section{Knuckle (2011)}

Dir: Ian Palmer

Prod: Teddy Leifer and Ian Palmer

Editor: Oliver Huddleston

Eileen Leahy is researching Community Filmmaking in Ireland, for a Ph.D., at Trinity College Dublin, funded by the Irish Research Council for the Humanities and Social Sciences. 


\section{Love/Hate - Series Two}

\section{Paul McGuirk}

The first series of Love/Hate, the 'crime-drama' produced by RTE \& Octagon Films, and broadcast on RTE television in the autumn of 2010, received respectable viewing figures and met with a mixed critical response. ${ }^{1}$ Bernice Harrison (2010), in The Irish Times, thought that the 'hard men', on whom the series focused, were a bit "soft around the edges" and "too nicely spoken” whereas Eilis O’Hanlon (2010), in The Sunday Independent - a newspaper which has produced considerable quantities of mythologizing copy about the activities of the denizens of 'gangland' - took exception to what she termed the transformation of "thicko skangers into heroes".

Created and written by Stuart Carolan, the first series introduced viewers to John Boy Power (Aidan Gillen), a moderately successful 'drugbaron', his wily lieutenant, Nidge (Tom Vaughan-Lawlor), and an assortment of minor hoods: Darren (Robert Sheehan), Tommy (Killian Scott), and Stumpy (Peter Campion). Given that none of his crew is up to any good, John Boy has difficulties holding them together. Darren's brother, Robbie (Chris Newman), on his release from prison, is murdered by a gang member but Darren is reluctant to take revenge as he is more concerned with the fact that Stumpy has impregnated his ex-girlfriend, Rosie (Ruth Negga). When Stumpy, suspecting that Rosie is still seeing Darren, beats her so badly that she loses their unborn child, Rosie prevails on Darren not to kill him. However, Stumpy, unwilling to rely on Darren's continued goodwill, shoots him and leaves him for dead. John Boy's half-brother, Hughie (Brian Gleeson)

1. On average, the four episodes drew a viewing audience of 400,000 according to Nielsen's TAM ratings. having admitted to John Boy that he killed Darren's brother Robbie, accidently kills himself while showing-off with a gun.

The Second series takes up a year after the point where the first left off with Darren working for Fran (Peter Coonan), a cigarette smuggler, loan shark and dog-fighting enthusiast, and getting back together with Rosie. When the Gardaí raid the hotel room where Tommy and Ado (Mark Dunn) are cutting a consignment of drugs, John Boy suspects Stumpy has been turned by the police. John Boy decides that Stumpy has to be "taken care of" and singles out Darren, who has been getting under his skin and owes him money, to do "the hit". When Rosie discovers that Darren has killed Stumpy, she leaves him. Having fallen foul of a creeping coke habit, John Boy becomes increasingly paranoid and unpredictable. Nidge, who has been looking after the day to day running of the business, decides that it is time for a change of leadership. With Darren's assistance, Nidge eliminates John Boy and takes over.

Love/Hate follows in the wake of several innovative television crime series emanating from the US in the last ten or twelve years. In HBO's The Sopranos, which ran for six seasons and eighty-six episodes from 1999 to 2007, David Chase, the series creator, and his writers, took the idea of the crime family that underpinned Godfather I \& II (Francis Ford Coppola, US, 1972 \& 1974) and turned it on its head. Instead of portraying the main characters as bourgeois businessmen caught up in complex machinations of post-war commerce, the series depicted Tony Soprano, his family and his criminal organisation as limited, blinkered, lower-middle-class aspirants. The tone of much of the writing was informed by an unusual degree of black comedy. Just as Robert Altman

ISSN 1699-311X 
had satirised American politics and culture in Nashville (US, 1976), Chase satirised American family and corporate values by focusing on a Mafia family from New Jersey. A sentimental psychopath, Tony Soprano wants to do right by his wife and children - but on his own terms. This apparently modest ambition, however, frequently leads to appalling outcomes for those people unfortunate enough to get in his way.

Series like The Sopranos and The Wire contextualise the lives and actions of their characters in various ways. ${ }^{2}$ In The Sopranos, Tony's therapy sessions with Doctor Melfi involve him having to rethink his focus on 'family values' in the face of her broader social analysis. The Wire, with its multi-protagonist, fractal narrative, adopts a more socio-political approach, where the spectator gets to see the marginalised inhabitants of the Baltimore projects create a counter-culture of underprivilege and disadvantage in a hostile commercial environment. Although The Wire started out looking like just another 'cop show', it quickly shifted perspective by focusing on the inter-connections between law-enforcement, street-crime, and politics in the city of Baltimore, Maryland. Rather than privileging the 'chain-ofcommand' that permeates City Hall and the local police precincts, and primarily serve the interests of the established business community, the series deconstructs the prevailing power structures, and explores how decisions made in the upperechelons of society play out at a lower level and how the ruling elite respond to the problems they themselves create.

Love/Hate, on the other hand, locates its action in 'gangland' - a mythological arena that has been conjured up by a number of the Irish tabloid newspapers over the last twenty years or so. Carolan focuses on the interpersonal relationships of a number of unremarkable characters whose involvement in the local drug trade is of itself unexceptional. None of the characters interact in any serious way with the 'outside-world'. Dublin itself is only glimpsed in

2. The Wire was created and written by David Simon and its 60 episodes were broadcast by HBO between 2002 \& 2008. fleeting montages evoking an anonymous postmodernist metropolis. The representatives of the outside world - Detective Kerrigan and John Boy's solicitor, Pat - are themselves depicted as denizens of 'gangland'.

Whereas The Sopranos succeeded in getting Tony's family and associates to stand in for America, Love/Hate does not examine the relationship between the criminal activities depicted in the series and Irish society as a whole. As presented thus far, the characters in Love/Hate are too one-dimensional to stand in for the broader complexities of Irish society. Few of the characters have more than one serious attachment. John Boy is a straightforward stock paranoid-psychopath. Everyone is out to get him but he is determined to get them first. When he discovers that his girlfriend Debbie is a junkie he immediately ditches her (though he has himself developed a serious coke-habit). Whereas Tony Soprano was constantly cultivating relationships with a wide range of people, relationships that gave rise to complicated conflicts of interest and loyalty, John Boy experiences no such conflicts. He is a narcissistic solipsist who simply bullies and intimidates everyone with whom he comes in contact. Everyone with whom he comes in contact is viewed as a means to an end or not 'seen' all. Unlike Tony Soprano, he never questions his own motives or actions. ${ }^{3}$ A crude and blinkered opportunism provides his only terms of reference. As a result, his malevolent downward-spiral accelerates throughout the series without any serious interruptions. It may well be that there really are people out there like just John Boy but figures like John Boy do not make for interesting or engaging dramatic characters. ${ }^{4}$

3. Much of Tony Soprano's soul-searching with Melfi is ironically depicted as an elaborate form of rationalisation.

4. David Chase has always insisted that the mobsters in The Sopranos are all incredibly stupid people, informed at best by a low cunning. But that is not to say that stupid 'characters' cannot have incredibly complicated lives that can be exploited dramatically. 
Burdened with the responsibility of introducing an element of moral ambiguity and conscience-wrestling into the proceedings, Darren and Rosie's storyline never rises above the banal. Right from the start the audience knows that Darren is a sensitive soul because his Dublin accent is not as flat as the rest of the cast. Having bludgeoned one of Fran's Rottweilers to death, after Fran set the dog on the homeless outcast, Luke (Gavin Dita), Darren is reluctantly drawn into the ambit of John Boy's affairs. Coerced into killing Stumpy, Darren gifts the 'blood-money' he receives for the 'hit' to Stumpy's mother. Despite this gesture of atonement, Rosie leaves him, suspecting that his overtly gentle demeanour conceals a disposition altogether more ruthless, and coldblooded. Nidge, the only character of any substance, does have conflicting attachments. He has to cope with John Boy's unpredictable mood-swings, his unequivocal devotion to his son Warren, his temperamental wife's pregnancy, and his sexual relationship with Linda (Danelia McCormac), Fran's wife. ${ }^{5}$ Where John Boy is brooding, selfpitying, and volatile, Nidge is clear-headed, unsentimental, and calculating. Where John Boy intimidates and bullies, Nidge cajoles and persuades. Where John Boy is myopically selfcentred, Nidge can make allowances for other people's short-comings and failings. When push comes to shove, he is just as ruthless as John Boy but his tipping point is more elastic.

The Sopranos encouraged its audience to identify with Tony, his family and associates. Week after week, it hammered home that when, pace Margaret Thatcher, 'there is no such thing as society', when the centre no longer holds, the individual is left with nothing but the crudest social-Darwinism to guide her or his way. Tony Soprano wants to think well of himself, to believe that reasonable principles guide his decisions, and that he adheres to a code which gives his actions some recognisable meaning. However, when push comes to shove, Tony does not have any values that tie him to the collective. The few loyalties to which he pretends stretch no

5. Tom Vaughan-Lawlor's performance packs more energy than any of the other leads; he leaves an audience in no doubt that he is fully committed to the part. further than his family - and even they are compromised by naked self-interest. The Sopranos developed this logic relentlessly, embroiling its audience in Tony and Carmella's domestic arrangements while demonstrating thebrutal reality upon which these scenes of familial normality were based.

Whereas The Sopranos implicated its audience in the dysfunctionality of its cast of characters, and made it aware of its complicity in the spread of neo-liberal moral indifference, Love/Hate, presents its audience with a group of people who are radically other, who occupy not just a parallel universe but a hermetically sealed parallel universe - 'gangland'. That is to say, Love/Hate allows its audience to dissociate itself from the activities and actions of John Boy and his crew rather than recognise and acknowledge the ideological and cultural chains that bind these two worlds together. Love/Hate persists in purveying the illusion that they are not us. They are not citizens of a democratic republic. They are the toxic residue produced by the activities of Ireland Inc, a defective by-product of 'Tiger' Ireland that must be disposed of.

But not only are John Boy's gang radically other, their existence does not impinge on the viewer in any concrete way. ${ }^{6}$ The title sequence of The Sopranos each week took us out of New York and into the New Jersey suburbs where papers were delivered and garbage collected. Each week, the programme took time establishing this location as somewhere many Americans live. Love/Hate gives us glimpses of Dublin in intermittent fast-edited montages that do not create any sense of place. John Boy's penthouse apartment, Nidge's home, Fran's 'yard', Luke's squat, the pub John Boy's crew frequents - none of these locations have an inhabited, lived-in feel. All of the characters appear unanchored, unattached to their surroundings, ungrounded in any recognisable

6. The only contemporary references in the course of the second series is a brief conversation between John Boy and his solicitor about changes in legislation requiring solicitors to disclose certain financial matters and a toast to the 'recession'. This is strange given that Carolan began his career writing current affairs satire for Newstalks' The Last Word. 
social milieu. ${ }^{7}$ It can be argued that this is a failing common to many films and TV series that tackle issues associated with contemporary urban crime. For example, it has been suggested that Gomorrah (Matteo Garrone, Italy, 2008) creates the impression that the "Camorra exists in a realm ruled by its own laws, a state within a state" and that what it fails to show:

...is the extent to which their system penetrates the city as a whole, into its historic heart as well as its commercial districts, corrupting the entire population's everyday life (Angrisani 2008).

As far back as 1978, Tony Garnet's Law \& Order series could, in four episodes, give a coherent sense of the social, political, economic, and ideological inter-connectedness of issues around law-breaking and law-enforcement. ${ }^{8}$ And David Simon described the second series of The Wire as:

a meditation on the death of work and the betrayal of the American working class ... it is a deliberate argument that unencumbered capitalism is not a substitute for social policy; that on its own, without a social compact, raw capitalism is destined to serve the few at the expense of the many (Simon 2005).

Finally, the language used by the characters in Love/Hate contributes nothing to the creation of any sense of a criminal ethos. Adam and Paul, in Lenny Abrahamson's film of the same name, had a particular way of talking to each other that reflected the dysfunctional way in which they thought about themselves and the world they

7. Many of the exterior scenes, shot in and around Inchicore, are so tightly photographed that even if the spectator is familiar with the locations it can be quite difficult to identify them.

8. Law \& Order was a four part BBC TV mini-series written by GF Newman, directed by Les Blair \& produced by Tony Garnet in 1978.

\section{Love/Hate (2011)}

Director: Anthony Byrne

Creator: Stuart Carolan

Cast: Aiden Gillen, Robert Sheehan, Ruth Negga inhabited. Similarly, both The Sopranos and The Wire deployed language in such a way as to signify not only the extent to which the various characters' thinking about the world was severely circumscribed but also as an index of their resistance to what they saw as a hostile social order. Of all the characters in Love/Hate, Nidge is the only one that has a distinctive way of expressing himself, and this is largely down to Vaughan-Lawlor's performance.

On the positive side, the series exhibits consistently high production values. It has a strong cast: Tom Vaughan-Lawlor, Ruth Bradley, Aoibhinn McGinnity, Peter Coonan, and Denise McCormac all turn in particularly persuasive performances. Stuart Carolan, a witty and intelligent writer whose 2004 play, Defender of the Faith, dealing with the implosion of a Republican family in South Armagh in the wake of the Hunger Strikes in the 1980s, is a powerful and serious piece of writing, would seem to be habituating himself to the mini-series format. And the general consensus would seem to be that the second series is a substantial an improvement on the first. According to RTE:

The average viewership for the second series as a whole was 530,000 viewers with a $31 \%$ share, a rise of 76,000 viewers and $3.5 \%$ share from the first four-part series which aired in October 2010. The most-watched episode of series two was episode five, which had an average audience of 659,000 with a $41 \%$ audience share. ${ }^{9}$

With that kind of audience endorsement, it should be possible for the producers and writers to open out the storylines in the planned third series to encompass contemporary socio-political issues that the genre allows and that series like The Sopranos and The Wire were able address, in admittedly different contexts.

9. http://www.rte.ie/ten/2011/1213/lovehate.html 


\section{Works Cited}

Angrisani, Silvia. 2008. “That’s Camorra”, Sight \& Sound, 18:11, November, pp. 20-1

Harrison, Bernice. 2010. “More Westlife Than Westies”, The Irish Times, 12 October

O’Hanlon, Eiilis. 2010. “How To Turn Thicko Skangers Into Heroes”, The Sunday Independent, 10 October

Vine, Richard. 2005. “Totally Wired”. The Guardian Unlimited, 4 September

Paul McGuirk lectures in European Cinemas at Trinity College Dublin and is currently working on a full-length study of Neil Jordan's work entitled From Modernism to Postmodernism: The Fiction \& Films of Neil Jordan. 


\section{Gabriel Byrne - Liminal Man}

\section{Roddy Flynn}

Being an immigrant here from Ireland I've always felt a disconnect between the country that I left and the country that I've come to. I'm very much aware that I'm an Irishman living in New York but I'm also aware that I'm an Irishman who belongs to the island of Ireland. I remember my daughter when she was about four, I was sitting by the bed doing the customary bedtime scéal and my daughter said "Dad, not another Irish myth, please."1

2011 saw Gabriel Byrne leave one career defining role to embrace another, both of which circulated around his particular brand of Irish male stardom in an American context. The role he left was that of psychotherapist Paul Weston, the lynchpin of the HBO drama series In Treatment. The role he stepped into was that of Irish Cultural Ambassador to America, a position created in the wake of the Irish Global Economic Forum at Farmleigh in 2009. Despite describing the job as lacking a remit, Byrne's words at the launch of the programme in the Lincoln Centre NYC nevertheless suggested a clear vision of the role of the artist in the creation rather than imitation of reality:

Every artist has the power to transform reality. That is the reality of politics, the reality of religion, the social reality. In fact, that's the job of the artist - is to be anarchic, is to question everything and out of that questioning to redefine a new reality and to a great extent the traditional modes of expression. ${ }^{2}$

This was very much in keeping with Culture Ireland's (the body which oversaw the Imagine

1. Gabriel Byrne on "Right Through the Very Heart of it” Broadcast on RTE Radio $131^{\text {st }}$ December 2011.

2. Quoted from a transcript of Byrne's speech at the official launch of Imagine Ireland on January 72011 in the Lincoln Centre, NYC.
Ireland programme) vision of the project as being to "reshape and reinvigorate notions of Ireland, what it means to be Irish and the potential for Ireland into the future."

In this regard, Byrne's appointment acknowledged his work over several decades in questioning popular representations of the Irish, especially within the United States. Eugene Downes, Chief Executive of Culture Ireland remarked that when he first met Byrne:

The range and depth of his vision for Irish culture in America threw down a gauntlet to everyone in the room. His thinking challenged us to develop a more ambitious strategy for cultural engagement that reflected the changing dynamics of Ireland's presence in the United States. ${ }^{3}$

Byrne's work as a Cultural Ambassador in the United States can therefore be extended beyond speeches at various cultural events or curating a MoMA programme of Irish cinema during 2011, and traced back to his breakthrough film role as Tom Regan in the 1990 gangster homage Miller's Crossing, through his pivotal role as Dean Keaton in The Usual Suspects and up to his more recent extended portrayal of Paul Weston.

Before considering these roles, it's worth rehearsing the basic facts of Byrne's background. Born in 1950 into what he identifies as a "solid working class family," he trained to become a priest at a seminary in England from age 12 to 17 , before abandoning the Church and training as a teacher. He turned to amateur-drama in 1975 and from there came to work at the Project Theatre (where he encountered Jim Sheridan, Liam Neeson, Neil Jordan, Ciaran Hinds, and

3. Eugene Downes in interview from Shelia Langan, "Imaging Ireland with Gabriel Byrne” Irish America Magazine, May 132011. 
Stephen Rea). Talent-spotted by John Boorman, he was cast as Uther Pendragon in Excalibur in 1980. A winning turn in RTE Television drama Bracken as a dark, brooding dairy farmer lead to a career-making role as a journalist who knows too much in the 1985 thriller Defence of the Realm. Hollywood soon beckoned (plus marriage and children with Ellen Barkin) and in the two decades following Miller's Crossing he's appeared in over thirty feature films. While these have included a number of Irish titles (The Courier, Frankie Starlight and Last of the High Kings) it is nonetheless surprising, particularly given the level of indigenous production activity in the past fifteen years, that he hasn't appeared in an Irish film since 1998.

Nevertheless, Byrne has consistently played Irish inflected characters: Tom Regan in Miller's Crossing, Dean Keaton in The Usual Suspects, Benjamin Madigan in the short-lived sitcom Madigan Men, Stewart Kane in Jindabyne the Australia-set adaptation of Raymond Carver's short story "So Much Water So Close to Home" and most recently, Paul Weston. All of these roles are played as Irish, or at least Irish American, despite the fact that with the exception of Madigan Men, the roles are not obviously written as such. Indeed in the case of Miller's Crossing, the character that became Tom Regan was originally Jewish whilst the role of Paul Weston is based on a character created by Israeli actor Assi Dayan.

That these characters "became" Irish was explicitly due to Byrne's intervention. And in at least some of these cases, Byrne argued for the foregrounding of this ethnicity. In a 1990 interview with US Premiere Magazine about Miller's Crossing he explained:

When I read the script out loud to myself, I said, "My God, this could have been written by somebody from Dublin!” When Byrne met the Coen brothers, he proposed playing the character with his accent. "We were skeptical", recalls Joel, "but we said, 'Fine, go ahead, try it.' He did it and we liked the way it sounded.

His most recent success, In Treatment was less adapted for American TV from its Israeli source material "Be' Tipul" than it was "translated": the characters are identical and they experience the same story arcs. Given this, making Paul Weston
Irish was a conscious digression from the original, one which Byrne apparently insisted upon:

"[T]he back-story I wanted to give him was that he emigrated to the States in his early teens and that he went back to Ireland to study at university. I find it interesting that there's no reference to the fact that he's Irish at all...At one point, a person who worked on the show asked me "Do you want to play this with a different accent?" I said 'Why would I do that?' He replied "Well, you might not be understood.” I said ‘I don’t think so.

Perhaps it's not surprising that an actor would seek to remain within his/her own ethnicity if the opportunity provides itself. However, Byrne's decision to remain "visibly" Irish in the roles he has chosen stands in stark contrast to say Colin Farrell, Liam Neeson or Pierce Brosnan. This raises the question of whether there is some significance behind Byrne's choices? Do they suggest an awareness of the currency of nationality (and in particular of Irish nationality)? That Byrne is conscious of the semiotics of Irishness is evident from his comments on the Revisiting The Quiet Man film series which he curated at MoMA in early summer 2011:

The aim is to raise - but not necessarily to answer - the questions 'Who are we as a group? How are we portrayed? How are we perceived?'. . . In terms of film, our story has, up to a certain point, been told for us, not by us. . .a great deal of what we know about each other as people comes from our knowledge of film.

In this respect, it is striking that most of the roles Byrne has opted to play Irish share a performance of masculinity that firmly rejects the deeply ingrained stereotype of physical violence. To be sure, violence is very much a part of Miller's Crossing, The Usual Suspects and Jindabyne. There is violence too in In Treatment, albeit more psychic than physical in nature. However, Byrne's characters are consistently reluctant to resort to violence themselves. This is reflected in Byrne's public persona, with interviewers stressing the "thoughtfulness with which he approaches every question and topic" (Langan 2011) and describing him as "a true man of letters and great intellectual curiosity” (Simon 2011). His casting as Paul Weston reflected the need for a star 
whose persona fitted with a show which was "dialogue-driven, relentlessly wordy and mostly about listening: not the stuff of action heroes.” Indeed Byrne is on the record as explicitly disavowing violence. Speaking from his experience with the Christian Brothers he notes that:

We got beaten around quite a lot. The result was I do not believe in corporal punishment, because I've suffered it. Corporal punishment degrades and humiliates. It teaches fear and radically affects self esteem. I think anyone who has been a victim of corporal punishment would be in a difficult position to put up a proposal for it.

Violence is also repeatedly visited upon Byrne's Irish characters. Virtually every character in Miller's Crossing assaults Tom at some stage in the film. In The Usual Suspects, he is beaten up during police questioning while in Jindabyne his best friend breaks his nose. And in In Treatment Paul Weston must endure constant verbal assaults from patients unwilling to confront their own frailties. Crucially, however, these characters do not respond in kind.

How are we to understand such stoicism? In her discussion of masochism as a response to a postwar crisis of masculinity refracted through the films of Jimmy Stewart, Amy Lawrence refers to the Stewart's alternation between "grotesquely distorted pain" and "a soft, almost erotic yielding" when his character is shot in The Man from Laramie. There is, however none of this in Byrne's playing. When Tom Regan is beaten up by thugs hired by Lazar, a bookie to whom Regan owes money, there's no sense of masochism at work. Rather Regan's response suggests a character who understands their own reality as one in which violence is a quotidian by-product of existence. He accepts it not as a product of his ethnic heritage, but of how things are in the world. Crucially, in a reversal of stereotype, he calmly and deliberately refuses to be drawn into it.

From Miller's Crossing onwards Byrne has, in the roles he has chosen and in the manner in which he has played them, repeatedly sought to play against the stereotypes of Irish screen masculinity. It might be further argued that he has sought to overtly construct Irishness as an identity upon which violence is visited, in a more politically balanced reflection of Irish history than has heretofore been made available in Anglo-American representations. In this regard it is worth considering how Byrne's conception of his own identity puts him in a position to reflect upon such images. As the quote at the beginning of this essay suggests Byrne's sense of identity is at least slightly fractured. In an interview with Irish America Magazine he insisted that he identified himself as Irish rather than Irish American but then entered the caveat that:

Home in the most profound spiritual sense is always Ireland. [But] your children determine where home is.

Byrne then occupies a uniquely liminal space, of Ireland but not in it and perhaps, then, perfectly positioned to reflect upon and contribute to how its people are represented. His public role as Cultural Ambassador can be seen as an extension of a clear-sighted artistic ambition to 'transform reality.'

\section{Work Cited}

Langan, Shelia. 2011. “Imagining Ireland with Gabriel Byrne” in Irish America Magazine, May.

Lawrence, Amy. 1998. "Jimmy Stewart is Being Beaten: Rope and the Postwar crisis in American Masculinity” Quarterly Review of Film and Video Vol 16 (1), pp 41-58.

Simon, Alex. 2011. “Gabriel Byrne: Talk to me” Venice Magazine, April

Roddy Flynn is a lecturer on film and television at the School of Communications, Dublin City University. 